\title{
STUDIES OF THE MASS BUDGET OF ARCTIC PACK-ICE FLOES*
}

\author{
By Arnold M. Hanson \\ (Department of Atmospheric Sciences, University of Washington, Seattle, Washington, U.S.A.)
}

\begin{abstract}
The processes of melting, freezing, precipitation, evaporation and condensation were considered in the computation of the mass budget of an ice floe in the northern Chukchi Sea. It was found that condensation and evaporation contribute negligible amounts, and that melting accounted for the largest loss from the upper surface of the floe. From an original mass of $270 \mathrm{~g} . \mathrm{cm} .^{-2}$, a unit ice column lost $9 \cdot 2 \mathrm{~g} . \mathrm{cm} .^{-2}$ by melting of snow and $35.2 \mathrm{~g} . \mathrm{cm} .^{-2}$ by melting of ice during the melt season. During the freezing period $5.8 \mathrm{~g} . \mathrm{cm} .^{-2}$ were regained by the accumulation of snow and frost. Measurements at the bottom of the ice indicate an estimated net loss of $5 \mathrm{~g} . \mathrm{cm} .^{-2}$ over a seven-month study. A comparison of six summers at three stations shows no obvious correlation of ablation and latitude, and an average loss of ice at the surface of $40 \mathrm{~g} . \mathrm{cm} .^{-2}$.
\end{abstract}

RÉsumé. Études du bilan de masse de floes du pack arctique. Dans l'établissement du bilan de masse d'un floe de la Mer Chukchi septentrionale, on a considéré les processus de fusion, gel, précipitation, évaporation et condensation. Il s'est avéré que les influences dues à la condensation et évaporation étaient négligeables, et que la plus grande perte était due à la fonte de la surface du floe. A partir d'une masse de $270 \mathrm{~g} \mathrm{~cm}^{-2}$, un cylindre unitaire de glace perdit $9,2 \mathrm{~g} \mathrm{~cm}^{-2}$ par fonte de neige et $35,2 \mathrm{~g} \mathrm{~cm}^{-2}$ par fonte de glace pendant la saison de fonte. Pendant la saison froide, $5,8 \mathrm{~g} \mathrm{~cm}^{-2} \mathrm{~s}$ 'accumulèrent par chute de neige et gel. Des mesures au bas du floe montrent une ablation nette d'environ $5 \mathrm{~g} \mathrm{~cm}^{-2}$ pour la période d'observation de sept mois. Les observations effectuées pendant six périodes estivales en trois stations ne montrent aucune corrélation entre l'ablation et la latitude, et une perte moyenne de glace à la surface de $40 \mathrm{~g} \mathrm{~cm}^{-2}$.

Zusammenfassung. Untersuchung des Massenhaushaltes arktischer Packeis-schollen. Unter Berücksichtigung beobachteter Werte von Ablation, Eisncubildung. Niederschlag, Verdunstung und Kondensation wird der Massenhaushalt einer Eisscholle in der nördlichen Tschuktschen-See berechnet. Es zeigt sich, dass Verdunstung und Kondensation nur unerhebliche Beiträge liefern und dass der grösste Massenverlust durch Abschmelzung an der Oberfläche eintritt. Sie reduziert die Ausgangsmasse einer Einheltssäule von $270 \mathrm{~g} \mathrm{~cm}^{-2}$ um $9,2 \mathrm{~g} \mathrm{~cm}^{-2}$ durch Schnee-Ablation und um weitere $35,2 \mathrm{~g} \mathrm{~cm}^{-2}$ durch Eis-Ablation in der Abschmelzperiode. In der Frostperiode beträgt die Akkumulation durch Schnee und Rauhreif $5,8 \mathrm{~g} \mathrm{~cm}^{-2}$. Messungen an der Unterseite der Eisscholle ergaben einen Nettoverlust von schätzungsweise $5 \mathrm{~g} \mathrm{~cm}^{-2}$ während eines 7-monatigen Beobachtungszeitraumes. Ein Vergleich von sechs Ablationsperioden an drei Stationen zeigt keine eindeutige Breitenabhängigkeit. Der durchschnittliche Eisverlust an der Oberfäche beträgt $40 \mathrm{~g} \mathrm{~cm}^{-2}$.

\section{INTRODUCTION}

The present report is mainly a study of the mass budget of U.S. drifting station "Charlie". Data from the preceding station "Alpha" and the succeeding station ARLIS II (Arctic Research Laboratory Ice Station) are used for comparisons.

Station "Alpha", which was used during the I.G.Y., was set up on drifting pack ice during April 1957 and abandoned in November 1958. During the 19 months of occupation the station drifted in the area bounded by lat. $79^{\circ}$ to $86 \cdot 5^{\circ} \mathrm{N}$. and long. 1 i $0^{\circ}$ to $176 \cdot 5^{\circ} \mathrm{W}$.

Station "Charlie" (also known as "Alpha II") was established on drifting pack ice during April 1959 and was withdrawn during January 1960. During this period it drifted in an area bounded by lat. $76^{\circ}$ to $78 \cdot 2^{\circ} \mathrm{N}$. and long. $159 \cdot 5^{\circ}$ to $\mathrm{I} 74 \cdot 4^{\circ} \mathrm{W}$.

ARLIS II is on an ice island. It was occupied in May r $96 \mathrm{I}$ at lat. $76^{\circ} \mathrm{N}$, long. $155^{\circ} \mathrm{W}$. and had, up to May r 964 , drifted with the Beaufort Sea gyral to lat. $86^{\circ} \mathrm{N}$., long $28^{\circ} \mathrm{W}$. Continuous studies of the sea ice adjacent to the island have been hampered by contamination and frequent ice movement. Only during the summer of 1963 , a small floe of clean pack ice $2.5 \mathrm{~m}$. thick was accessible for measurements of ablation.

The budget described here pertains to the mass of a column of unit cross-sectional area and a length equal to the mean thickness of the floe. By assuming densities (Untersteiner, I96r) of $0.9 \mathrm{~g} . \mathrm{cm}^{-3}$ for the ice, errors smaller than those from other sources are introduced.

The mass changes considered in the computation of the mass budget at station "Charlie"

* Contribution 86, Department of Atmospheric Sciences, University of Washington, Seattle. 
were melting, freezing, precipitation, evaporation and condensation. Internal melting was considered to have no net effect.

\section{Methods}

The mass of the snow cover was measured just before the onset of the melt season by more than four hundred measurements of the snow depth.

The amount of ice melt at the upper surface of the floe was determined from several sets of white wooden ablation stakes set in the ice approximately $\mathrm{I} \mathrm{m}$. deep at the time the snow disappeared. Pond stakes were set in the lower areas where melt water had saturated the snow.

The accretion or ablation of the lower surface of the floe was determined from thickness measurements made by drill holes and by thickness gauges devised by Untersteiner and Badgley (1958) (Fig. I).

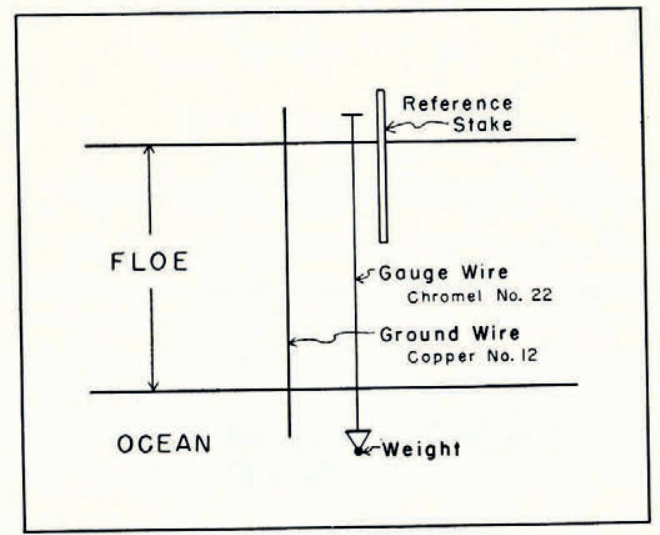

Fig. I. Thickness gauge to measure ice bottom accretion or ablation

Observations of evaporation, condensation and/or sublimation were carried out by weighing two clear "Plexiglass" pans which were filled with wet snow or disintegrated ice and placed with the pan tops even with the surface. The pans had an area of $500 \mathrm{~cm}^{2}$, were $\mathrm{I} \cdot 5$ and $2.0 \mathrm{~cm}$. deep and had walls approximately $2 \mathrm{~mm}$. thick. (Pans of different depths showed no systematic difference in the mass changes of their contents.)

During the melt season (June to mid-August) measurements of the ablation stakes and weighing of the evaporation pans were made twice daily, which also permitted calculation of diurnal changes. After the termination of the melt season the stakes and the thickness gauges were measured several times each month.

A water level recorder which can be used to determine changes in ice thickness was in operation at station "Charlie". A description of the use of this instrument for such purposes has been given by Untersteiner and Badgley (1958). The rise of the floe of $37 \cdot 5 \mathrm{~cm}$. observed between 2I June and 3I August corresponds to a surface ablation of $4 \mathrm{I} \cdot 7 \mathrm{~cm}$., in almost perfect agreement with the stake measurements.

\section{Results}

\section{Upper surface}

The measurements of snow depth preceding the melt season ranged from o to $122 \mathrm{~cm}$; the average was $28 \mathrm{~cm}$. With a density of $0.33 \mathrm{~g} . \mathrm{cm}^{-2}$, as found at station "Alpha" 
(Untersteiner, $\mathrm{I}_{96 \mathrm{I}}$ ), this amounts to $9 \cdot 2 \mathrm{~g} . \mathrm{cm} .^{-2}$. At the end of the melt season the amount of the winter snow cover remaining on the floe was estimated to be less than $\mathrm{I}$ per cent.

Solid precipitation (snow and frost) during the melt season amounted to $2 \cdot 82 \mathrm{~cm}$. when melted, all of which for purposes of mass budget calculations was assumed to have melted. Table I gives monthly totals of precipitation measurements by U.S. Weather Bureau personnel on station "Charlie". From the end of the melt season to the end of the year snow and frost accumulation amounted to $5 \cdot 8 \mathrm{~g}$. (Table II).

Table I. Station “Charlie”, Monthly Precipitation (cm. of water)

\begin{tabular}{|c|c|c|c|c|c|}
\hline Type & 7une & 7uly & August & September & $\begin{array}{c}\text { Total } \\
\text { 7une-September }\end{array}$ \\
\hline Rain, drizzle & $0 \cdot 15$ & $0 \cdot 18$ & $0 \cdot 43$ & $0 \cdot 13$ & 0.89 \\
\hline Snow & 0.08 & I $\cdot 93$ & trace & $0.8 \mathrm{I}$ & $2 \cdot 82$ \\
\hline Total precipitation & 0.23 & $2 \cdot$ II & $0 \cdot 43$ & $0 \cdot 94$ & $3 \cdot 71$ \\
\hline
\end{tabular}

Table II. Heights of Snow and Frost Deposit (cm.)

$\begin{array}{ccr}\begin{array}{c}\text { Period } \\ \text { 1959 }\end{array} & \text { Increment } & \text { Total } \\ \text { 15-31 August } & 0.7 & \\ \text { 25 September } & 2 \cdot 1 & 2 \cdot 7 \\ \text { 28 October } & 6 \cdot 0 & 8 \cdot 8 \\ \text { 27 November } & 5 \cdot 3 & 14.1 \\ \text { 31 December } & 3.6 & 17.7\end{array}$

Net accumulation (density $0.33 \mathrm{~g} \cdot \mathrm{cm} \cdot{ }^{-3}$ ) $=5.8 \mathrm{~g} . \mathrm{cm} \cdot{ }^{-2}$.

Snow melt and formation of ponds began in June. The ablation values during 5-day periods in non-ponded areas as computed from two sets of ablation stakes are given in Table III. A "weighted total" is given because stake set II incompletely spans the melt season.

Table III. 5-Daily Ice Ablation of Non-ponded Areas (cm.), 20 June-20 August 1959

\begin{tabular}{|c|c|c|c|c|}
\hline $\begin{array}{c}\text { Period } \\
\text { ending } \\
\text { I } 959\end{array}$ & Set $I$ & $\begin{array}{c}\text { Number of } \\
\text { stakes }\end{array}$ & Set II & $\begin{array}{c}\text { Number of } \\
\text { stakes }\end{array}$ \\
\hline 26 June & $6 \cdot 9$ & 4 to $6 *$ & - & o \\
\hline I July & $6 \cdot \widehat{6}$ & 6 & 一 & o \\
\hline 6 July & $\mathrm{I} \cdot \mathrm{I} \dagger$ & 6 & 一 & o \\
\hline I I July & $\mathrm{I} \cdot 3$ & 6 & 一 & o \\
\hline 16 July & $2 \cdot 5 \dagger$ & 6 & 一 & o \\
\hline 21 July & $3 \cdot 3$ & 6 to $\mathrm{II}^{*}$ & 一 & o \\
\hline 26 July & $4 \cdot \mathrm{I}$ & I I & $3 \cdot 0$ (3 days) & Io \\
\hline 3I July & $\mathrm{I} \cdot 4^{\dagger}$ & I I & $2 \cdot 7$ & 10 \\
\hline 5 August & $4 \cdot 7$ & I I & $5 \cdot 4$ & Io \\
\hline Io August & $3 \cdot 7$ & I I & $3 \cdot 8$ & Io \\
\hline I5 August & $2.55^{\dagger}$ & 8 & $2 \cdot 7$ & Io \\
\hline 20 August & 0.0 & 8 & $0 \cdot 0$ & IO \\
\hline \multirow[t]{3}{*}{ Total } & $3^{8 \cdot 1}$ & & $17 \cdot 6$ & \\
\hline & \multicolumn{2}{|c|}{ Weighted total } & $39.2 \mathrm{~cm}$. & \\
\hline & \multicolumn{2}{|c|}{ Mass, using $0.9 \mathrm{~g} . \mathrm{cm}^{-3}$} & $35 \cdot 3 \mathrm{~g} \cdot \mathrm{cm} .^{-2}$ & \\
\hline
\end{tabular}

* Number of stakes increased.

$\dagger$ Snow or frost during interval. 
Table IV. Pond Ablation (cm.), Minimum Values

\begin{tabular}{|c|c|c|c|}
\hline $\begin{array}{c}\text { Period } \\
1959\end{array}$ & Pond $I^{*}$ & Pond $2 \dagger$ & Pond 3 \\
\hline $\begin{array}{l}25 \text { June-18 July } \\
18 \text { July-1 I August } \\
\text { II August-10 September }\end{array}$ & $\begin{array}{l}4^{1} \cdot 8 \\
-\end{array}$ & $\begin{array}{l}33 \cdot 4 \\
28 \cdot 0 \\
-\end{array}$ & $\begin{array}{l}39 \cdot 7 \\
46 \cdot 6 \\
11 \cdot 9\end{array}$ \\
\hline Total melt & - & $6 r \cdot 4$ & $98 \cdot 2$ \\
\hline \multirow{2}{*}{\multicolumn{2}{|c|}{$\begin{array}{l}\text { Pond depth at end of season } \\
\text { Net mass lost using } 0.9 \mathrm{~g} . \mathrm{cm}^{-3}\end{array}$}} & $37 \cdot 1$ & $58 \cdot 9$ \\
\hline & & $18 \cdot 2 \mathrm{~g} \cdot \mathrm{cm} .^{-2}$ & $29.5 \mathrm{~g} . \mathrm{cm}^{-2}$ \\
\hline
\end{tabular}

* Pond I measurements were discontinued after it filled with drifting snow.

$\dagger$ Pond 2 measurements were discontinued after the surface froze.

The "weighted net loss for all ponds" given in Table IV was computed by using; the three intervals shown in Table IV. Pond 2 was about twice the area of pond I but only one-seventh the area of pond 3, and therefore the "net loss" included areal weighting. The difference in the amount of melt in any interval between ponds was due in the main part to differences in pond depth and ice type and to a lesser part to errors of measurement.

Diurnal differences in melt rate were observed. The data analysed by half-day periods is shown in Table $\mathrm{V}$. The pond melting rate was smoother by almost a factor of two.

Table V. Mean Diurnal Ablation Rates (mm.)

$\begin{array}{ccccc}\begin{array}{c}\text { Period } \\ \text { I959 }\end{array} & \text { Location } & \text { Day } & \text { Night } & \text { 24-hr. rate } \\ & & & \\ \text { 25 June-23 July } & \text { 3 ponds } & 9 \cdot 8 & 5 \cdot 0 & 14 \cdot 8 \\ \text { 22 June-14 August } & \text { Stake set I } & 7 \cdot 8 & 2 \cdot 0 & 9 \cdot 8 \\ \text { 23 July-I4 August } & \text { Stake set II } & 7 \cdot 8 & \text { I.7 } & 9 \cdot 5\end{array}$

\section{Lower surface}

Ice thickness measurements were made at two sites by drilling; these were helpful not only to determine changes of thickness but also for the study of "false bottoms" and under-ice ponds. A "false bottom" is a thin layer of ice which forms in summer underneath the floe where fresh water lies between the salt water and the ice; this is described by Untersteiner and Badgley (1958). Measurements of the thickness of a "false bottom" are accurate to I cm.

The results obtained by repeated drilling in a small pond with natural drainage are shown in Figure 2a. The formation of two fresh-water under-ice ponds indicates that there must have been two periods of pond drainage in this area prior to the initiation of measurements. The floe continued to thin after the pond froze over, because of the supply of heat from the fresh-water pond and from short-wave radiation passing through the clear pond ice and water.

At another site near an artificial drainage hole the under-ice pond had vanished between I9 and 30 August (Fig. 2b). All drilling at this site was near an ablation stake which served as a datum plane. The step in the false bottom which occurred between I9 and 2 I July was probably caused by the escape of some of the under-floe pond water.

Bottom ablation and accumulation measurements by thickness gauges were initiated in September (Table VI); three of these gauges had been installed through under-ice ponds. Ablation continued at the "false bottom" of the floe well into the winter season (shown by gauges 2 and 3 in December). The large variation of the net thickness change was caused by differences in ice thickness, snow depth and by the presence or absence of surface and under-ice ponds, as well as by the variable amount of water within the floe. 

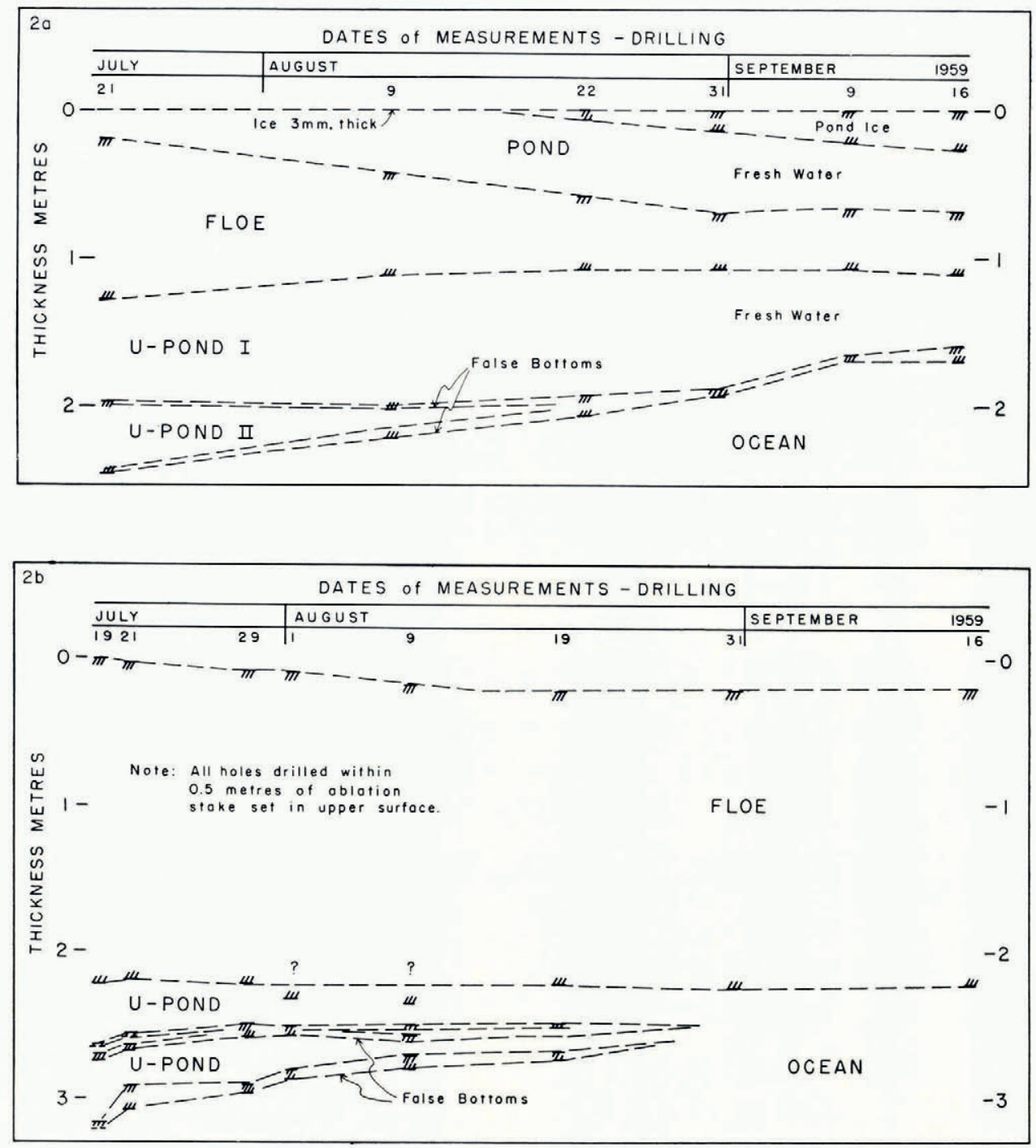

Fig. 2. (a) Time cross-section of floe at a site with both surface pond and under-floe pond near natural drain hole. (b) Time crosssection of floe near artificial drain hole

\section{Discussion}

Measurements of the initial ice thickness of the floe at six points within the study site area ranged from $\mathrm{I} \cdot 5$ to $5.2 \mathrm{~m}$., with an average of $2.9 \mathrm{~m}$. The mass of a unit ice column, including $9.2 \mathrm{~g} . \mathrm{cm}^{-2}$ of snow, was estimated as $270 \mathrm{~g} . \mathrm{cm}^{-2}$ at the start of the ablation season.

The amounts of evaporation and condensation were so nearly in balance and were so small $\left(\mathrm{mg} . \mathrm{cm}^{-2}\right.$ day $\left.^{-1}\right)$ that these processes have been neglected in the analysis.

The mass loss at the upper surface of the floe (Tables I, III and IV) was calculated as a weighted mean of areas free of and covered by ponds, reduced by the amount of refrozen pond water. The largest source of error in the pond ablation measurements was caused by the 


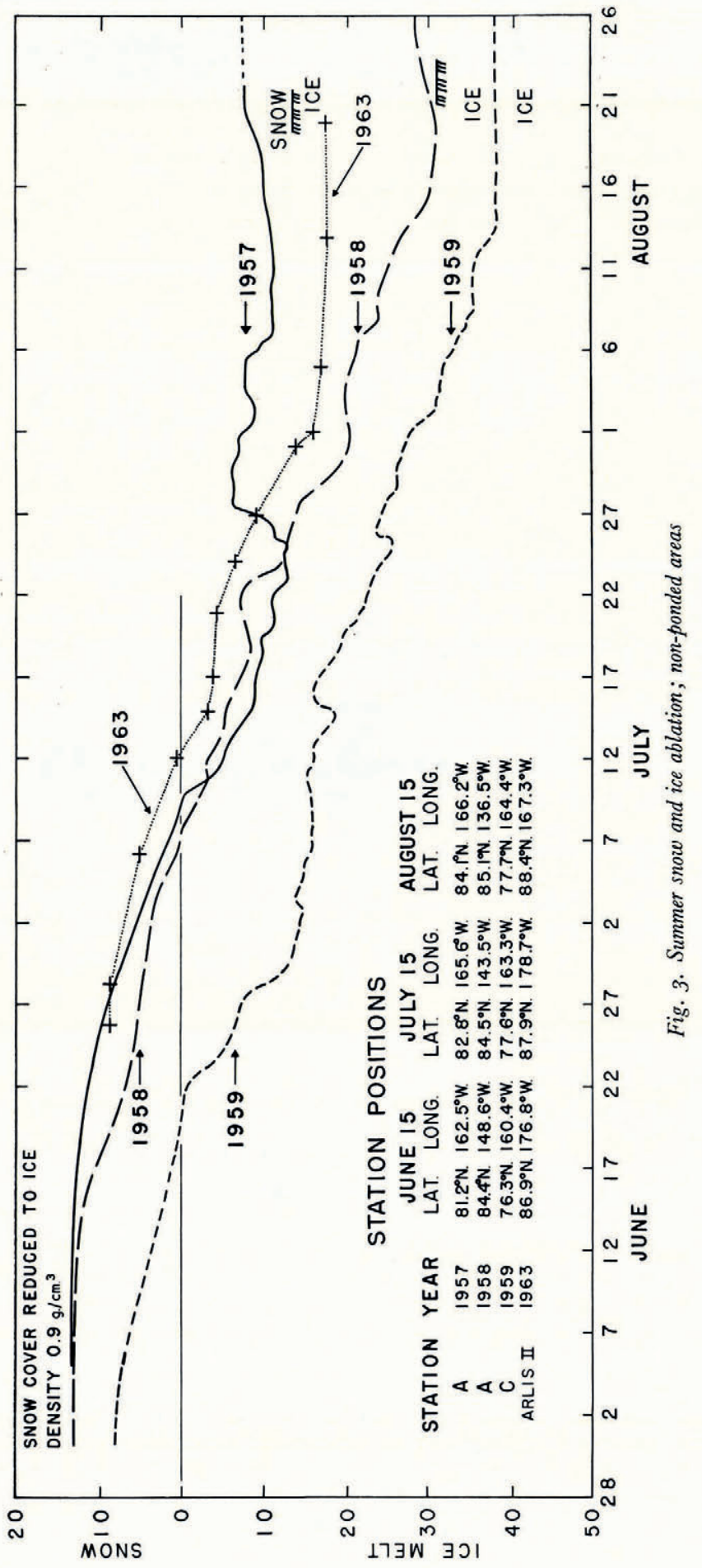




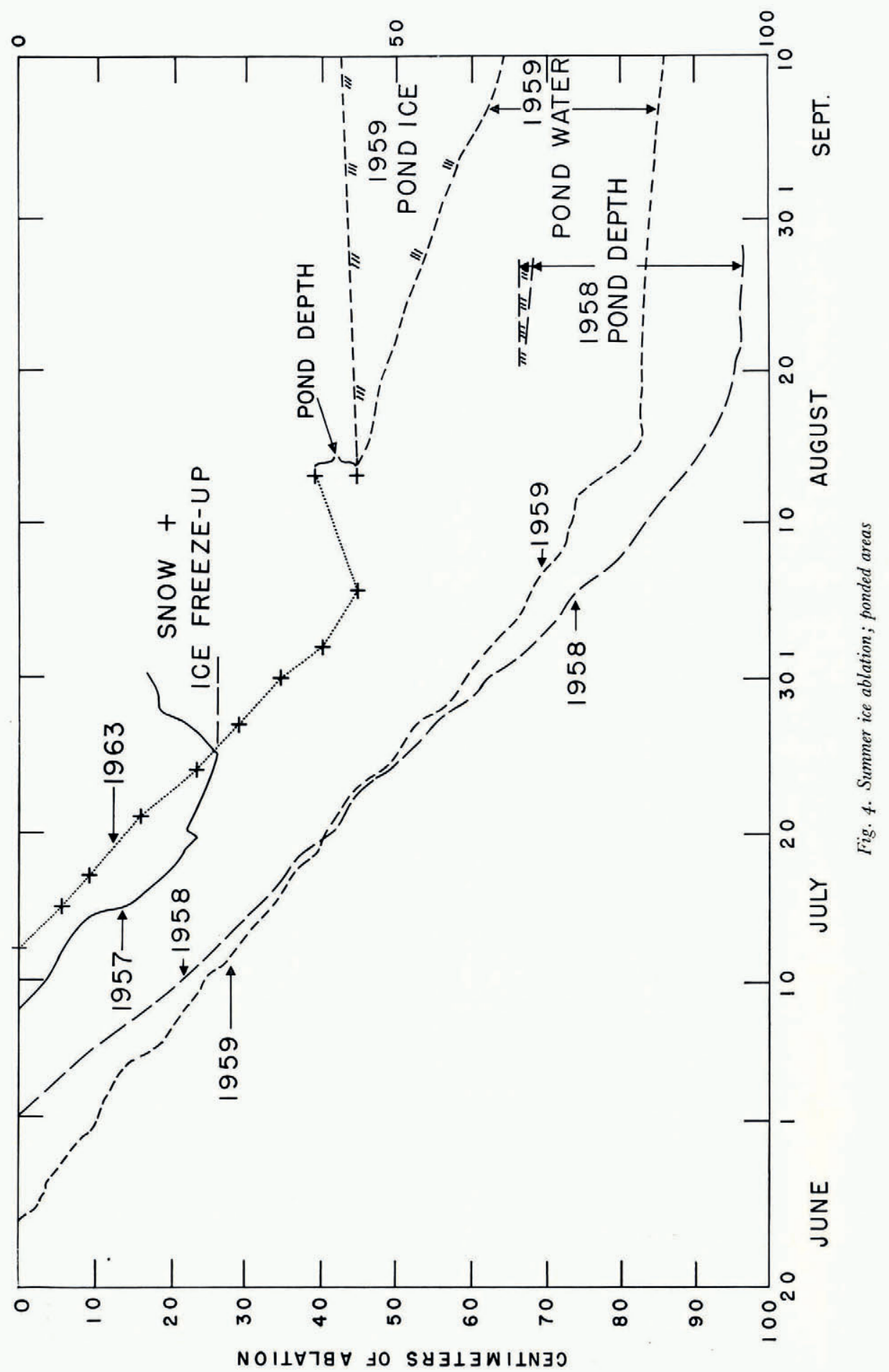


ablation stakes melting loose. An analysis of the pond ablation measurements gave a minimum value for the melt in the ponds. The actual loss was probably slightly greater.

The amount of ice gained or lost from the bottom of the floe was not well determined owing to the unknown fraction of the total surface which had under-floe ponding, but the best estimate from drilling is that under-floe ponds covered approximately one-half the floe bottom. The under-floe ponds, no doubt, protect the floe bottom from ablation; in fact some accretion can be expected (Untersteiner and Badgley, 1958). From the drilling and thicknessgauge measurements it is estimated that, while more than $9 \mathrm{~g}$. of ice was lost by ablation, there was an average accretion of $6 \cdot 3 \mathrm{~g}$. (average of gauges I, 4, 5 and 6; Table VI). The data of Table VI alone show a near balance in ablation and accretion, but the installation dates extend over a five-week period beginning after the end of the surface melt season. In the absence of the insulating effect of under-floe ponds, a larger bottom ablation would probably have been measured and also a larger accretion. A summary of the mass balance for station "Charlie" is presented in Table VII. From June through December approximately 20 per cent of the original mass was lost.

Table VI. Bottom Ablation and Accretion (in cm.), as Determined by Thickness Gauges

\section{Gauge No. I}

\begin{tabular}{|c|c|c|c|}
\hline & Thickness & Ablation & $\begin{array}{c}\text { Accre } \\
\text { tion }\end{array}$ \\
\hline Date began & \multicolumn{3}{|l|}{2 September } \\
\hline & $45^{\circ} \cdot 0$ & - & - \\
\hline $\begin{array}{l}30 \text { September } \\
29 \text { October }\end{array}$ & $44^{2} \cdot 5$ & $7 \cdot 5$ & \\
\hline $\begin{array}{l}29 \text { October } \\
29 \text { November }\end{array}$ & $\begin{array}{l}442 \cdot 2 \\
442 \cdot 6\end{array}$ & $\underline{0.3}$ & 0.4 \\
\hline 21 December & $443 \cdot 2$ & - & 0.6 \\
\hline \multicolumn{2}{|c|}{ Total } & $7 \cdot 8$ & $1 \cdot 0$ \\
\hline \multicolumn{2}{|c|}{ Net thickness change } & $-6 \cdot 8$ & \\
\hline
\end{tabular}

\section{Gauge No. 4}

\begin{tabular}{cccc} 
& Thickness & Ablation & $\begin{array}{c}\text { Accre- } \\
\text { tion }\end{array}$ \\
Date began & 28 September \\
& $307 \cdot 0$ & - & - \\
30 September & $307 \cdot 2$ & - & $0 \cdot 2$ \\
29 October & $305 \cdot 0$ & $2 \cdot 2$ & - \\
29 November & $305 \cdot 5$ & - & $0 \cdot 5$ \\
21 December & $309 \cdot 8$ & - & $4 \cdot 3$ \\
Total & & $2 \cdot 2$ & $5 \cdot 0$ \\
\multicolumn{2}{c}{ Net thickness change } & $2 \cdot 8$
\end{tabular}

\begin{tabular}{lcc}
\multicolumn{3}{c}{ Gauge No. 2* } \\
\multicolumn{4}{c}{ Accre- } \\
Thickness Ablation & tion \\
I5 September \\
$252 \cdot 7$ & - & - \\
$251 \cdot 3$ & $1 \cdot 4$ & - \\
$249 \cdot 0$ & $2 \cdot 3$ & - \\
$248 \cdot 8$ & $0 \cdot 2$ & - \\
$247 \cdot 5$ & $1 \cdot 3$ & - \\
\multicolumn{4}{c}{} \\
& $5 \cdot 2$ & - \\
& $-5 \cdot 2$ &
\end{tabular}

Gauge No. $5^{+}$

Thickness Accre30 September

$\begin{array}{rrr}268.6 & - & - \\ 274.4 & - & 5.8 \\ 276.4 & - & 2.0 \\ 284.3 & - & 7 \cdot 9 \\ 294.2 & - & 9.9 \\ & - & 25.6 \\ & 25.6 & \end{array}$

Gauge No. $3 \dagger$

$\begin{array}{ccc}\text { Thickness } & \text { Ablation } & \begin{array}{c}\text { Accre- } \\ \text { tion }\end{array} \\ 28 \text { August } & & \\ 221 \cdot 0 & - & - \\ 204.9 & \mathrm{I} 6 \cdot \mathrm{I} & - \\ 199 \cdot 7 & 5 \cdot 2 & - \\ 200 \cdot 6 & - & 0.9 \\ 198 \cdot 3 & 2 \cdot 3 & - \\ & 23.6 & 0.9 \\ & -22 \cdot 7 & \end{array}$

Gauge No. 6

$\begin{array}{ccc}\begin{array}{c}\text { Thickness } \\ 3 \text { October }\end{array} & \text { Ablation } & \begin{array}{c}\text { Accre- } \\ \text { tion }\end{array} \\ 198.1 & - & - \\ - & - & - \\ 195.6 & 2.5 & - \\ 193.6 & 2.0 & - \\ 204.4 & - & 10.8 \\ & 4.5 & 10.8 \\ & 6.3 & \end{array}$

* Under-floe pond $8 \mathrm{r} \mathrm{cm}$. thick.

† Under-floe pond $28 \mathrm{~cm}$. thick; also surface pond with $26 \mathrm{~cm}$. water and I I cm. ice.

‡ Surface pond with $3 \mathrm{~cm}$. water and $31 \mathrm{~cm}$. ice.

Table ViI. Station “Charlie”, Mass Budget for June-December 1959 (g. cm. ${ }^{-2}$ )

Gain/Loss Balance

Initial mass

Loss of initial snow cover

Solid precipitation during melt season, all of which melted

Surface ice melt

Snow and frost

Bottom ablation

Bottom accretion
$270 \cdot 0$

$\begin{array}{ll}-9 \cdot 2 & 260.8\end{array}$

9.8
+263.6

$-2.8 \quad 260.8$
-33.8

$-33.8 \quad 227.0$

532.8
+5.8

$\begin{array}{rr}10.0 & 222.8\end{array}$

$+6.3 \quad 228$. I 
In Figures 3 and 4 melt season curves of four summers at three stations are presented. Furthermore, a summary of the net losses for the summers of 1957 , I958, I959, I96 I, I962 and 1963 , which have been adjusted according to estimates of pond area and remaining pond water, show rather wide variations (Table VIII). Apparently, the effect of latitude is outweighed by the variations of weather conditions during individual summers.

The $70 \mathrm{~cm}$. melt estimated for ${ }^{1} 9^{6} \mathrm{I}$ is based on the measurement of the ablation of approximately $\mathrm{I} \mathrm{m}$. of contaminated ice. Similarly, for 1962 the measurement of the melt of contaminated ice was approximately $30 \mathrm{~cm}$.

Table ViII. Comparison of Loss due to Melting of the Upper Surface of Pack Ice (g. $\mathrm{cm}^{-2}$ )

\begin{tabular}{|c|c|c|c|}
\hline \multicolumn{2}{|c|}{ Station/Year } & Net loss & Latitude \\
\hline "Alpha" & I957 & $3^{2}$ & $80-85^{\circ} \mathrm{N}$. \\
\hline "Alpha" & $195^{8}$ & 53 & $84-86^{\circ} \mathrm{N}$. \\
\hline "Charlie" & I959 & 46 & $76-78^{\circ} \mathrm{N}$. \\
\hline ARLIS II & 1961 & $(70) *$ & $73-76^{\circ} \mathrm{N}$ \\
\hline ARLIS II & 1962 & $(20) *$ & $8 \mathrm{I}-83 \cdot 4^{\circ} \mathrm{N}$ \\
\hline ARLIS II & I963 & 28 & $86-88.5^{\circ} \mathrm{N}$ \\
\hline
\end{tabular}

* Estimated (see text).

For energy budget calculations it must be considered that the total mass of ice melted is greater than the net loss by the amount of water retained in surface ponds. It may vary between 5 and 25 per cent of the total melt. An average of $40 \mathrm{~g} . \mathrm{cm}^{-2}$ (Table VIII) appears to be a reasonable value of the average net loss of mass from the upper surface of old clean pack ice in the Arctic Ocean.

\section{Acknowledgement}

The research reported in this paper was sponsored by the Geography Branch of the Office of Naval Research under Contract Number 477(24) with the University of Washington.

MS. received 23 June 1964

\section{REFERENCES}

Untersteiner, N. r961. On the mass and heat budget of Arctic sea ice. Archiv für Meteorologie, Geophysik und Bioklimatologie, Ser. A, Bd. 12, Ht. 2, p. $15 \mathrm{I}-82$.

Untersteiner, N., and Badgley, F. I. 1958. Preliminary results of thermal budget studies on Arctic pack ice during summer and autumn. (In Arctic sea ice. Washington, D.C., p. 85 92. ([U.S.] National Academy of SciencesNational Research Council Publication 598.)) 